\title{
Polyculture of tilapia (Oreochromis niloticus) and lemeduk (Barbonymus schwanenfeldii) in floating net cages as a strategy for utilizing natural food
}

\author{
Nurfadillah Nurfadillah ${ }^{1,2,3^{*}}$, Iwan Hasri ${ }^{4}$, and Fahrial Fahma ${ }^{1}$ \\ ${ }^{1}$ Department of Aquaculture, Faculty of Marine and Fisheries Universitas Syiah Kuala, Banda Aceh, Indonesia \\ ${ }^{2}$ Laboratory of Marine Biology, Faculty of Marine and Fisheries, Universitas Syiah Kuala, Banda Aceh \\ ${ }^{3}$ Research Center for Marine and Fishery, Universitas Syiah Kuala, Banda Aceh, Indonesia \\ ${ }^{4}$ Department of Fisheries Aceh Tengah, Aceh Tengah
}

\begin{abstract}
Polyculture is a sustainable aquaculture system because it can reduce environmental pollution and increase feeding efficiency. The purpose of this study was to analyze the performance of growth, biomass and food competition for tilapia as the main commodity and lemeduk fish as a secondary commodity with a polyculture system in floating net cages. The research method used a Completely Randomized Design (CRD) consisting of 5 treatments and 3 replications, namely: treatment A (60 tilapia fish), Treatment B (40 tilapia fish +20 lemeduk fish), Treatment C (30 tilapia fish +30 lemeduk fish), Treatment D (20 tilapia fish +40 lemeduk fish), and Treatment E (60 lemeduk fish). The research container uses floating net cages with a size of $0.5 \times 0.5 \times 1 \mathrm{~m}$. Parameters observed were absolute length growth, absolute weight growth, specific growth rate, biomass production, competition index, and water quality. The results showed that the polyculture system of tilapia and lemeduk at different stocking densities had a significant effect on absolute length growth, specific growth rate, biomass production, and had low competition between tilapia and lemeduk. The best treatment was found in treatment B (N 40+ L 20) and treatment C (N 30+ L 30) with absolute length growth value $3.20 \mathrm{~cm} \pm 0.17$, specific growth rate $3.83 \% \pm 0.36$, biomass of tilapia 94.36 $\mathrm{g} / 0.5 \mathrm{~m}^{2} \pm 16.45$ and total biomass $100.69 \mathrm{~g} / 0.5 \mathrm{~m}^{2} \pm 5.49$. Hence, the polyculture system is better than the monoculture system and the absence of competition between tilapia and lemeduk in using food.
\end{abstract}

\section{Introduction}

The growth of floating net cages in flooded waters is very rapid and often causes environmental problems. The impact of fish farming activities in cage culture can cause the water quality of stagnant waters to decrease. The decrease happened because of the leftover feed waste. So far, the majority of fish farming systems in cage culture use a monoculture system. Just one type of fish that we can keep is Tilapia. Because Tilapia is continuous demand and availability of seeds. In addition, tilapia is one type of fish that has economic value and important commodity in the freshwater fish business because tilapia has beneficial properties, such as: easy to breed, fast growth, and easy to grow in intensive aquaculture systems [1].

Polyculture is a sustainable aquaculture system because it reduces the environmental impact of activities by increasing the efficiency of feeding. A polyculture system in which one contains two or more species are raised together [2]. The benefit of using this system is a high level of land productivity. In principle, there are several things related to products that must be regulated so that there is no competition between products in obtaining their feed. Besides, each product is expected to be able to take advantage of each other so that circulation occurs in one cultivation location [3].

Lemeduk fish (B. schwanenfeldii) is a native fish in the inland of Aceh, one of which is Laut Tawar Lake. This fish is called Tengadak fish in Kalimantan and Kapiat in Riau. This fish is a herbivorous species [45]. Based on Pulungan [6] said that this fish is classified as an omnivorous fish and does not interfere with the types of small fish in the waters where it lives. Based on the eating habits of these fish, it is expected that they can eat the rest of the feed and natural feed derived from organic matter that is wasted in the waters. In addition, lemeduk fish are expected to be able to take advantage of the moss that grows in the net. Lemeduk fish is also a promising aquaculture commodity in the future due to the relatively fast growth of large fish, good meat taste, and low trophic level.

The polyculture of tilapia and lemeduk has never been carried out in cage culture, so it is necessary to research the polyculture of tilapia and lemeduk with different stocking densities. Research on polyculture has been carried out on several commodities including Windu Shrimp with Milkfish [7], Larasati Red Tilapia and Milkfish [8], Goldfish and Nilem [9], Tilapia with native fish in Laut Tawar lake (Lemeduk, Depik, and Peres fish) [10]. This study is to analyze monoculture

\footnotetext{
*Corresponding author: nurfadillah@unsyiah.ac.id
} 
and polyculture systems of Tilapia (Oreochromis niloticus) and Lemeduk (Barbonymus schwanenfeldii) with different stocking densities in cage culture covering the performance of growth, biomass and competition of tilapia as the main commodity and lemeduk as a secondary commodity.

\section{Methodology}

\subsection{Sampling and experimental design}

The research was carried out at the UPTD Fish Seed xfrom August - September 2020. The research method used is the experimental method. The aim was obtained data and test the feasibility of fish farming with polyculture and monoculture systems using the floating net cages that has been proposed. The study used a oneway Completely Randomized Design (CRD), consisting of five treatments and three replications, namely N60 (60 Tilapia fish $/ 0.25 \mathrm{~m}^{2}$ ), N40+L20 (40 Tilapia fish $/ 0.25 \mathrm{~m}^{2}$ and 20 Lemeduk fish $\left./ 0.25 \mathrm{~m}^{2}\right), \mathrm{N} 30+\mathrm{L} 30(30$ Tilapia fish $/ 0.25 \mathrm{~m}^{2}$ and 30 Lemeduk fish $/ 0.25 \mathrm{~m}^{2}$ ), $\mathrm{N} 20+\mathrm{L} 40$ (20 Tilapia fish $/ 0.25 \mathrm{~m}^{2}$ and 40 Lemeduk fish $/ 0.25 \mathrm{~m}^{2}$ ), L60 (60 Lemeduk fish $/ 0.25 \mathrm{~m}^{2}$ ).

\subsection{Research procedure}

This study used 15 happa containers. Fish seeds to be stocked are 1-3 cm long, then kept in $2 \times 2 \mathrm{~m}^{2}$ nets. The fish are acclimatized so that the fish can adapt to the environment. Feed given the fish for tilapia seeds during the study was in the form of floating type commercial pellets. The frequency of feeding was twice a day, in the morning and evening with a total of $8 \%$ of the weight of fish biomass per experimental unit. Data collection was carried out 4 times during the study with a duration of once per 10 days.

\subsection{Evaluation of growth performance of Tilapia and Lemeduk}

The parameters of growth performance were obtained by according to study Thongprajukaew [11] and Ferosekhan [12] using the following equations:

\subsubsection{Absolute length growth}

Absolute length growth is used to calculate fish length gain during rearing:

$$
\begin{aligned}
& \quad L=L t-L o \\
& \text { Note: } \\
& \mathrm{L}=\text { absolute length growth }(\mathrm{cm}) \\
& \mathrm{Lt}=\text { Final average length }(\mathrm{cm}) \\
& \text { Lo = Initial average length }(\mathrm{cm})
\end{aligned}
$$

\subsubsection{Absolute weight growth}

Absolute weight gain was used to calculate the weight gain of fish biomass during rearing:

$$
W=W t-W o
$$

Note:

$\mathrm{W}=$ absolute weight growth $(\mathrm{g})$
$\mathrm{Wt}=$ Average weight of fish at time $\mathrm{t}(\mathrm{g})$

Wo $=$ Average weight of fish at the start $(\mathrm{g})$

\subsubsection{Fish Specific Growth Rate}

The specific growth rate is the $\%$ of the difference between the final weight and the initial weight, divided by the length of maintenance time:

$$
S G R=\frac{\text { LnWt }- \text { LnWo }}{t} \times 100 \%
$$

Note:

$\mathrm{SGR}=$ Specific growth rate $(\% /$ day $)$

$\mathrm{Wt}=$ final body weight $(\mathrm{g})$

Wo $=$ initial body weight $(\mathrm{g})$

$\mathrm{t}=$ Maintenance time (days)

\subsubsection{Biomass}

Biomass is the resultant between survival and average final weight:

$$
B M=W t x N t
$$

Note:

$\mathrm{BM}=$ Biomass

$\mathrm{Wt}=$ Total Weight of Fish contained in the culture container $(\mathrm{g})$

$\mathrm{Nt}=$ Total number of fish at the end of the study (fish)

\subsubsection{Competition Index}

Criteria for determining the opportunity for competition between fish species:

$$
\mathrm{IK}=\frac{a-b}{a}
$$

Note:

$\mathrm{IK}=$ Competition Index

$\mathrm{a}=$ single cultivation biomass $(\mathrm{g})$

$\mathrm{b}=$ Production of mixed cultivation biomass $(\mathrm{g})$

\subsection{Water quality monitoring}

Water quality measurements will be carried out at the beginning of the study, in the middle and at the end of the study. Measurements were carried out on day 1, day 20 and day 40. The parameters observed were temperature and degree of acidity $(\mathrm{pH})$.

\subsection{Data analysis}

The data in this study were subjected to the one-way analysis of variant (one-way ANOVA) test and followed by Least Significant Difference tests (LSD) and Duncans test. The significant difference was determined at $P<0.05$.

\section{Result}

The results of polyculture and monoculture studies of tilapia and lemeduk using the cage culture system showed the increase in length and weight with increasing time (Figure 1a and 1b). The results showed that the highest length increase was in the N20+L40 treatment and the lowest was in the N60 treatment. 

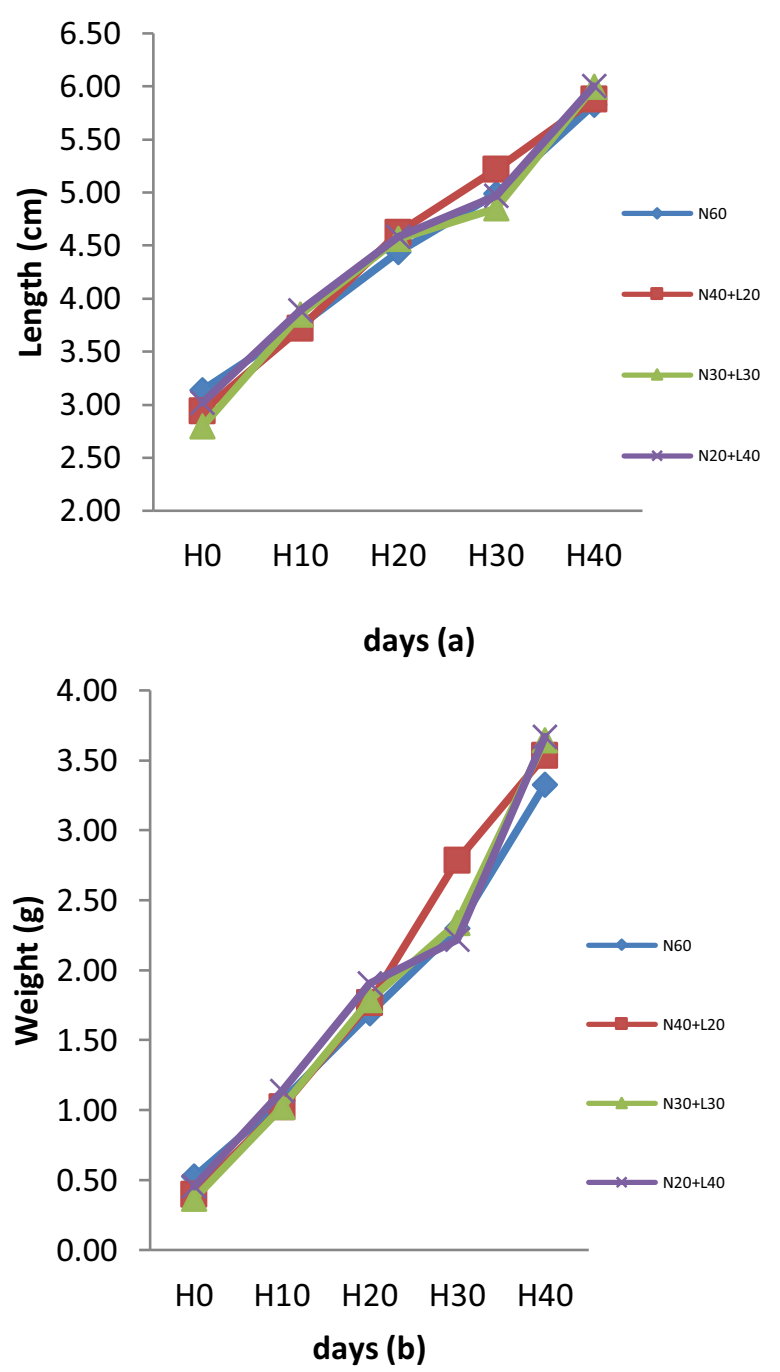

Fig. 1. Growth Performance of monoculture and polyculture of Oreochromis niloticus with Barbonymus schwanenfeldii in floating net cages (a) Increase in fish length; (b) Fish weight gain.

The results also showed that the growth of lemeduk in both length and weight in polyculture and monoculture systems with tilapia in the cage culture system showed that the growth in length and weight increased with time. The highest absolute weight growth was in the treatment $\mathrm{N} 30+\mathrm{L} 30(0.48 \mathrm{~g} \pm 0.13)$ and the smallest was in the treatment $\mathrm{N} 40+\mathrm{N} 20(0.28 \mathrm{~g} \pm 0.13)$ (Figure 2a). Length growth was also highest in the treatment $\mathrm{N} 30+\mathrm{N} 30(1.24 \mathrm{~cm} \pm 0.11)$, then the lowest in the treatment $\mathrm{N} 20+\mathrm{L} 40(0.72 \mathrm{~cm} \pm 0.20)$.

Based on the results of the ANOVA test, the treatment of tilapia reared in a with lemeduk showed a significant effect in increasing the absolute length of tilapia, the specific growth of tilapia, and the biomass of tilapia and the total biomass of the polyculture system for each treatment $(\mathrm{p}<0.05)$. So it can be concluded that the tilapia polyculture system with lemeduk fish succeeded in increasing the biomass and it means that there is one treatment (polyculture) which has a significant effect when compared to the effect of the non-polyculture system and with other treatments (Table 1).

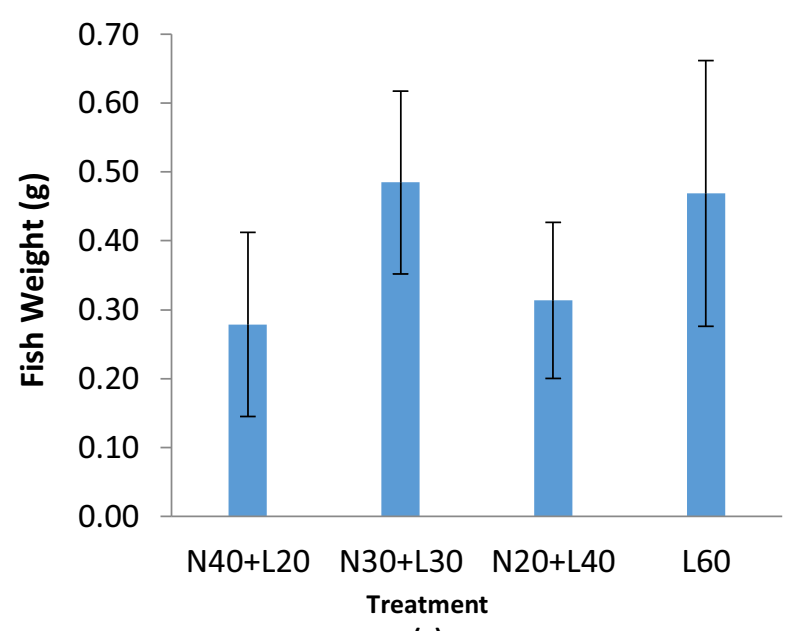

(a)

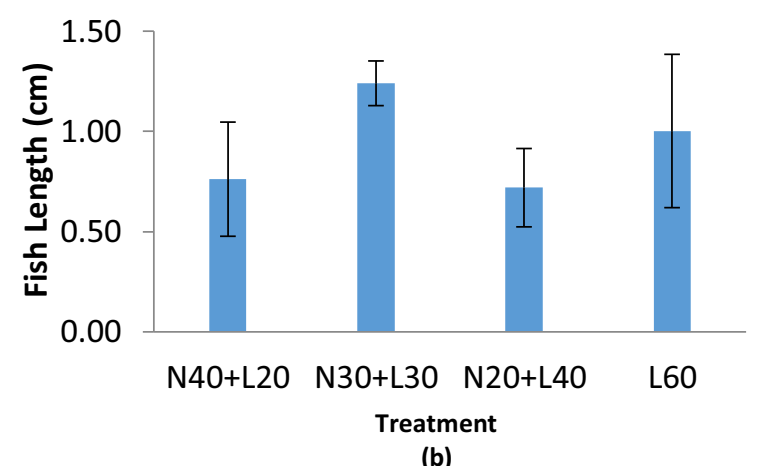

Fig. 2. (a) Absolute Weight Growth; (b) Growth of Absolute Length Monoculture and Polyculture of Oreochromis niloticus with Barbonymus schwanenfeldii in floating net cages.

Tilapia reared by a polyculture system with lemeduk showed no significant effect in increasing the absolute weight gain of tilapia ( $p>0.05)$. So it can be concluded that the tilapia polyculture system with lemeduk did not succeed in increasing the absolute weight of tilapia.

The highest absolute length growth value was in the $\mathrm{N} 30+\mathrm{L} 30$ treatment $(3.20 \mathrm{~cm} \pm 0.17)$ and the lowest was in the N60 treatment $(2.69 \mathrm{~cm} \pm 0.10)$. The results of further LSD tests showed that the treatment N30+L30 was not significantly different from the treatment $\mathrm{N} 40+\mathrm{L} 20$ and N20+L40 but significantly different from N60.

The specific growth of tilapia was highest in the treatment $\mathrm{N} 30+\mathrm{L} 30(3.83 \% \pm 0.36)$ and the lowest was in the treatment $\mathrm{N} 60(2.83 \% \pm 0.05)$. The results of the further LSD test showed that the best treatment was treatment $\mathrm{N} 30+\mathrm{L} 30$ not significantly different from treatment $\mathrm{N} 40+\mathrm{L} 20$ and $\mathrm{N} 20+\mathrm{L} 40$ but significantly different from treatment N60. The highest biomass of tilapia in each treatment was in the N60 treatment $\left(94.36 \mathrm{~g} / 0.5 \mathrm{~m}^{2} \pm 16.45\right)$ and the lowest was in the treatment $\mathrm{N} 20+\mathrm{L} 40\left(41.23 \mathrm{~g} / 0.5 \mathrm{~m}^{2} \pm 5.31\right)$.

The competition index obtained in this study shows that the competition index for tilapia and lemeduk is negative in all treatments (Table 2). This negative value shows that in the applied polyculture the presence of 
lemeduk fish does not affect tilapia, especially competition in terms of getting food, oxygen and space.

Tabel 1. Absolute length growth, absolute weight growth, specific growth of tilapia, tilapia biomass, and total biomass Monoculture and Polyculture of Oreochromis niloticus with Barbonymus schwanenfeldii in floating net cages.

\begin{tabular}{|c|c|c|c|c|c|}
\hline \multirow[t]{2}{*}{ Treatment } & \multicolumn{5}{|c|}{ Research Parameters } \\
\hline & $\begin{array}{c}\text { Tilapia Absolute } \\
\text { Length Gain }(\mathrm{cm})\end{array}$ & $\begin{array}{l}\text { Tilapia Absolute } \\
\text { Weight Gain (g) }\end{array}$ & $\begin{array}{c}\text { Tilapia Specific } \\
\text { Growth Rate (\%) }\end{array}$ & $\begin{array}{c}\text { Tilapia Biomass } \\
\left(\mathrm{g} / 0.25 \mathrm{~m}^{2}\right)\end{array}$ & 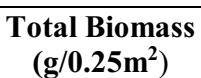 \\
\hline N60 & $2.69 \pm 0.10^{\mathrm{a}}$ & $2.82 \pm 0.01^{\mathrm{a}}$ & $2.83 \pm 0.05^{\mathrm{a}}$ & $94.36 \pm 16.45^{\mathrm{b}}$ & $100.69 \pm 5.49 \mathrm{~b}$ \\
\hline N40+L20 & $2.94 \pm 0.19^{\mathrm{ab}}$ & $3.15 \pm 0.26^{\mathrm{a}}$ & $3.60 \pm 0.39^{b}$ & $72.61 \pm 12.72^{b}$ & $75.85 \pm 6.96 b$ \\
\hline N30+L30 & $3.20 \pm 0.17^{b}$ & $3.34 \pm 0.42^{\mathrm{a}}$ & $3.83 \pm 0.36^{\mathrm{b}}$ & $78.64 \pm 18.30^{\mathrm{b}}$ & $80.26 \pm 11.24 b$ \\
\hline $\mathbf{N 2 0 + L 4 0}$ & $2.99 \pm 0.14^{\mathrm{ab}}$ & $3.15 \pm 0.23^{\mathrm{a}}$ & $3.29 \pm 0.22^{\mathrm{ab}}$ & $41.23 \pm 5.31^{\mathrm{a}}$ & $51.66 \pm 2.16 \mathrm{a}$ \\
\hline
\end{tabular}

Note: Different superscript letters in the same column show significant differences $(\mathrm{P}<0.05)$

Table 2. Results of the competition index parameters.

\begin{tabular}{|l|c|c|}
\hline \multirow{2}{*}{ Treatment } & \multicolumn{2}{c|}{ Competition Index } \\
\cline { 2 - 3 } & Tilapia & Lemeduk \\
\hline Tilapia & - & - \\
\hline Tilapia 30+Lemeduk 30 & -0.23 & -6.47 \\
\hline Tilapia 20+ Lemeduk 40 & -0.43 & -2.98 \\
\hline Tilapia 40+ Lemeduk 20 & -0.09 & -13.36 \\
\hline
\end{tabular}

The water quality observed in the research were temperature parameters and degrees of acidity $(\mathrm{pH})$. The temperature values range from $22.5-23.7^{\circ} \mathrm{C}, \mathrm{pH}$ values range from $6.9-7.1$, the values of the two parameters are still in optimal conditions for fish growth [27;28].

\section{Discussion}

The increase in absolute length growth and specific growth of tilapia in polyculture studies of tilapia and lemeduk with different stocking densities showed that the treatments of N30+L30, N20+L40 and N40+L20 were not significantly different. This shows that the difference in stocking density of lemeduk fish does not cause slow growth of tilapia length. It can be said that the lemeduk polyculture fish did not interfere with the growth of tilapia. The increase in the length of the lemeduk, along with the length of the tilapia, showed that the polyculture system applied to fish was able to grow the main fish and by-products simultaneously, resulting in the same growth synergism between fish species. Growth is characterized by changes in length and weight in a certain period [13].

The factors that affect the absolute length growth and specific growth of fish during the study are feed availability. The feed was given a floating type with a feed ration of $8 \%$ of the weight of the fish biomass being reared.. Factors that affect growth are feed rations and fish weight while other factors are external and internal factors [14-16]. Tilapia growth is good because the feed provided contains protein following the body's needs for both energy and growth [17-19]. In addition, the water quality in the research container is good to support the growth of pet fish. Herawati and Suantika [20] increased growth rate was related to the increasing average weight of tilapia seeds and water quality.

The absolute weight growth was not significantly different between the treatments N30+L30, N20+L40 and N40+L20. However, the absolute weight growth of fish was highest in the N30+L30 treatment. The high rate of this treatment indicates that the balanced stocking density of tilapia and lemeduk causes no competition so that the polyculture system allows fish to take advantage of the food available in their rearing environment. The high density of sinking water plants in the form of Hydrilla verticilata in the research location container also causes the availability of natural food for lemeduk fish to be well available. According to Mudjiman [21] statement that Tawes fish when they are still seeds like to eat plankton. After growing up, Tawes fish like to eat moss and young algae shoot in line with Muryanto and Sumarno [22] that Tawes fish are herbivores that eat aquatic plants, phytoplankton, molluscs, insects, periphyton, moss and detritus that are in a net container as a maintenance container. The implication is that water recirculation from and outside the net goes well so that the quality of polyculture water for tilapia and lemeduk is relatively good, resulting in better growth of tilapia with lemeduk.

Tilapia biomass and total biomass in polyculture systems with lemeduk were influenced by survival and fish weight at the end of rearing. The biomass of tilapia in monoculture treatment was higher than that of fish in polyculture because the density of tilapia in monoculture was higher than that of tilapia in polyculture. Tilapia biomass value is determined by survival rate, growth rate and stocking density [23-25]. Lante et al [23] polyculture vaname shrimp had higher production than monoculture with rostris shrimp and tiger prawns. The high biomass of lemeduk fish is caused because the fish feed given to tilapia can be utilized optimally by tilapia.

This study showed that with the addition of lemeduk there was no competition between tilapia and lemeduk in all different stocking density compositions because lemeduk fish were waiting for feed in the water column, in contrast to tilapia which took feed to the surface and then brought it to the water column. The research Nurfadillah et al. [10] that there is no competition between tilapia and native fish in Laut Tawar lake. Lante et al [23] and Bayu et al [26] also stated that polyculturereared tiger prawns, Vaname and Rostris did not cause competition between shrimps reared. The absence of competition can be seen in negative values (Table 2). During the maintenance period, it can be seen that at the time of feeding there was no competition. Tilapia are more active in taking food and bringing it to the water column than lemeduk fish. In addition, fish that are polyculture with tilapia can take advantage of the natural feed which is available in the container. 


\section{Conclusion}

A polyculture system is better than monoculture. The best polycultures with different stocking densities were shown in the treatment of N40+L20 and N30+L30 on the parameters of absolute length, specific growth rate, tilapia biomass and total biomass.

\section{References}

1. S. E. Wardoyo, Media Akuakultur, 2 (2007)

2. L. V. Arana, Fundamentos de aquicultura. Florianopolis, UFSC. (2004)

3. U. Kholifah, N. Trisyani, I. Yuniar, Neptunus J, 14 (2008)

4. I. I. Kusmini, R. Gustiano, I. Mulyasari, G.H. Huwoyon, Ikan lokal tengadak (Barbonymus schwanenfeldii) asal Kali-mantan sebagai andalan untuk ikan budi daya dalam Prosiding Seminar Nasional Ikan ke-8, 3-4 Juni 2014, Bogor, Indonesia (2015)

5. R. H. Gunawan, Z.A. Muchlisin, S. Mellisa, Jurnal Ilmiah Mahasiswa Kelautan dan Perikanan Unsyiah, 2 (2017)

6. C. P. Pulungan, The potential for kapiek fish cultivation from the Kampar River, Riau (Research Center Universitas Riau. Pekanbaru 73, 1987).

7. M. Mangampa, Polikultur udang windu (penaeus monodon), bandeng (Chanos chanos), nila srikandi (Oreochromis aureus $x$ o. niloticus), dan rumput laut (Gracilaria verrucosa) di tambak tanah sulfat masam (TSM) dalam Prosiding Forum Inovasi Teknologi Akuakultur, 1, 13 (2014)

8. I. Samidjan, D. Rachmawati, A. Indarjo, H. Panggono, Pengembangan teknologi polikultur ikan nila merah larasati (Oreochromis niloticus) dan ikan bandeng (Chanos chanos forskal) berbasis penggunaan probiotik untuk percepatan pertumbuhan dan kelulushidupan dalam menunjang agromina kota pekalongan, dalam Prosiding Seminar Nasional Kelautan, 27 Juli 2016, Universitas Trunojoyo Madura, Indonesia (2016)

9. A. K. Putri, Zahidah, S.A. Harahap, Journal of Marine Fisheries, 7, 1 (2016)

10. N. Nurfadillah, I. Hasri, R. Fahmi, Misran, The competition index and growth performance between tilapia (Oreochromis niloticus) and native fish spesies Laut Tawar Lake in polyculture system, in IOP Conference Series: Earth and Environmental Science, 24 September 2020, Banda Aceh, Indonesia (2021)

11. K. Thongprajukaew, S. Pettawee, S. Muangthong, S. Saekhow, W. Phromkunthong, Aquaculture Research. J, 50 (2019)

12. S. Ferosekhan, S. K. Sahoo, K. Radhakrishnan, P. Velmurugan, N. Shamna, S.S. Giri, B.R. Pillai, Aquaculture, 521 (2020)
13. P. Yuliati, T. Kadarini, S. Subandiyah, Jurnal Ikhtiologi, 3 (2017)

14. M. I. Effendi, Metode Biologi Perikanan (Yayasan Dwi Sri, Foundation, Bogor, 1997)

15. B. Hepher, Nutrition of Pond Fishes, Formerly of Fish and Aquaculture Research Station, (Cambridge, University Press, 1988)

16. C. J. Jaspe, C. Caipang, B.J.G. Elle, Animal Biology \& Animal Husbandry, 3, 2 (2011)

17. C. Miroslav, T. Dejana, L. Dragana, D.J. Vesna, Tehnologija Mesa, 52, 1 (2011)

18. H. Djajasewaka, Fish Feed, (CV Yasaguna, Jakarta, 1995)

19. S. S. De Silva, A. Anderson, Fish nurtrition in Aquaculture (The Fish Edition, Chapman and Hall, London 1995)

20. Herawati, G. Suantika, DisSainTek, 1, 1 (2007)

21. Mujiman, Makanan Ikan, (Jakarta: CV. Simplex, 2000)

22. T. Muryanto, D. Sumarno, Jurnal Teknis BPPKSD Jatiluhur, 11, 1 (2014)

23. S. Lante, H.S. Suwoyo, M. Mangapa, (Balai Besar Riset Perikanan Jakarta: Pengembangan Teknologi Budidaya Perikanan, 2012).

24. R. Iskandar, Elrifadah, Jurnal Ziraa"ah, 40, 1 (2015)

25. M. K. Anam, F. Basuki, L.L. Widowati, Jurnal sains akuakultur tropis, 1, 1 (2017)

26. R. Bayu, H. Hamdani, Yuniarti, Jurnal Perikanan dan Kelautan, 3, 3 (2012)

27. Farida, E.I. Raharjo, M. Sahrio, Jurnal Ruaya, 4, 2 (2016)

28. G. H. Huwoyon, I.I. Kusmini, Jurnal Ikhtiologi Indonesia, 10, 1 (2010) 